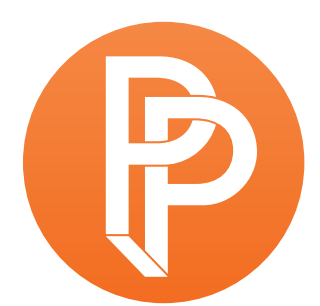

PERFORMANCE

PHILOSOPHY

\title{
WHAT IS PHILO-PERFORMANCE? AROUNDTABLE
}

\author{
AMALIA BOYER, FLORE GARCIN MARROU, CHARLOTTE HESS, MARIA KAKOGIANNI, \\ LIZA KHAROUBI, ESA KIRKKOPELTO, CAMILLE LOUIS, MARIELLE PÉLISSÉRO, MÉLANIE \\ PERRIER, NADIA VADORI-GAUTHIER, ALINE WIAME
}

TRANSLATED BY VIRGINIE GIREL-PIETKA

This article is an edited transcript of the roundtable entitled "What is Philo-Performance?" that took place in Paris on 28 June 2014, within the framework of the "Theatre, Performance, Philosophy International Conference: Crossings and Transfers in Anglo-American Thought". The conference was organized by Julien Alliot, Flore Garcin-Marrou, Liza Kharoubi and Anna Street from the LAPS, a French research group on performance philosophy. The contributors are very grateful to Laura Cull for offering them the chance to publish this transcript here and to Virginie Girel-Pietka for translating it into English.

Flore Garcin-Marrou: Good afternoon, everybody and welcome to our roundtable. Let me briefly introduce myself. I have been exploring the relations between philosophy and theatre for a long time, ever since I wrote my doctoral dissertation on Deleuze, Guattari and theatre (2006-2011) at the University of Paris-Sorbonne. (See Garcin-Marrou 2014a, 2013, 2012). That is why I first organized a symposium on the subject in 2012 at the Ecole Normale Supérieure (Panopoulos and Garcin-Marrou 2012) and then launched the LAPS research group (http://labo-laps.com/). Moving on to the present conference, I thought of this round-table because all of us here have specific affinities with one another. What brings us together is the fact that we all address thought and art 
at once: blending them, experimenting with new forms of exchange, and making a point of getting acquainted with other researchers who share our intentions. We are here today to discuss what philo-performance is. First of all, I will venture to say that none of us here is fully satisfied with that term. It sounds attractive and yet somewhat inadequate. Yesterday, in her presentation on the young queer stage in France, Muriel Plana talked to us about a "perfo-conference" during which body language and articulated speech intermingled (Plana 2014). In a similar vein, the Ajàso group from Toulouse University presented us with a documentary film directed by Gentian Koçi and focusing on that collective desire to take philosophy beyond the university walls and let it meet 'the Outside' (http://tpp2014.com/fr/projection-de-films/). How can thought excite our senses and allow us to channel our various responses into a collective creative act? The time has come to share our experience. Who would like to start the discussion?

Camille Louis: Thank you, Flore, for initiating this event. I am a playwright and a PhD candidate at Paris 8 university, where I am also a lecturer. My dissertation is entitled: La Recomposition du politique dans la décomposition des politiques ("Re-membering Politics While Dismembering Policies"). I am studying the way practical, aesthetic approaches to politics, such as those exemplified in contemporary artistic practices, may initiate a new brand of political thought by paying as much attention to bodies, gestures and the performative dimensions of people gathered, as to statements and speeches. Politics and its current evolution are thus freed from the theoretical framework of so-called "political philosophy", according to which nothing actually happens when crowds rise and occupy places. My practice as a dramatist feeds such research and, five years ago, the connection between performance and politics led me to launch an interdisciplinary European research group, "kom.post" (http://kompost.me). The group aims at experimenting with the displacement of philosophy into the field of performance through interactive events, which shed new light on the relationship between spectators, performers and author. When Flore suggested the term "philo-performance", I thought it was very puzzling since some contributors to the present conference take it for granted that philosophy is performative, that there are performative moments in philosophy... Yet I do not feel that this is that obvious. For instance, I have been thinking over Martin Puchner's talk. To him, the performativity of philosophy is to be found in philosophical scenes, namely 'scenes of instruction' (Puchner 2014). To me, such scenes nonetheless rely on specific relations of power... Muriel Plana's very interesting talk then made us aware of the fact that one of the performative tasks of performance and philosophy might lie in their ability to question stock images and the hierarchy of power inherent in a capitalist society. This endows performance, as well as any other action initiated by thought and creativity, with a political dimension. And yet, even if performance indeed consists in challenging established ideas, all brands of philosophy are not necessarily performative. Performance philosophy is a controversial, problematic and issue-raising philosophical endeavour that is far from obvious. The term "philo-performance" is interesting insofar as this ultimate blend of philosophy with performance refers us to what distinguishes one from the other, and to the fact that there are common points between them that may be uncovered in the course of our peculiar experiments in search of them. 
Flore Garcin-Marrou: The term "philo-performance" was suggested about ten years ago by Charlotte Hess in a manifesto posted on the website of Zones d'attraction'.

Charlotte Hess: Good afternoon. I am a tango dancer and a performer. I used to study both performing arts and philosophy at Paris 8 University. The group of artists named "philoperformance" came together ten years ago, with the intention to stage thought. We have come a long way since then. The term "philo-performance" is puzzling indeed. It is often said that the performance of thought mainly aims at putting "highbrow" philosophy in people's reach through art. Art is understood as a didactic tool that purports to enlighten people, to explain to people what they are experiencing. What we tried to do is quite the reverse! We attempted to uncover the way any gesture reveals some underlying thought and the way thought might prove performative in that it initiates common, everyday gestures. What I cannot abide, in the common use of the concept, is that "philosophy" is used to mean some academic subject, "highbrow" thought, or rationality. Whereas to me, "philo-performance" is the thought that is to be found in everyday life, in practical experiences, in social scenes which most of all allow us to think through collective experiences and the fact of being together.

Liza Kharoubi: I work as a lecturer in contemporary British theatre at the University of Avignon and I am pleased to be a co-organizer of this conference. The whole event has been conceived as a response to a need for gesture within the realm of philosophy, and of thought in general, in an attempt to uncover what is alive in the act of thinking, the creativity that underlies it, as well as what is inherently speculative in the artistic gesture in particular. The whole project is challenging too. It allows us to probe that space which emerges in-between philosophy and performance, and to correct the view that this merely has to do with "decorating" philosophy with gestures. It is rather about reaching a point when something is actually happening - such is the intent underpinning Alphonso Lingis's work.

Marielle Pélisséro: I am a PhD candidate at Paris Ouest - Nanterre University. I am focusing on the emergence of performance in France since the 1960s, and on the necessity of such a concept and the ways it is used. I am also surveying the relationships initiated by performance between the individuals who take part in a theatre workshop (Labex Arts $\mathrm{H} 2 \mathrm{H}$ 2014). In the course of this conference I chaired the session dedicated to the Gesture research group (Laboratoire du Geste). Something very interesting happened as far as gesture and speculation are concerned. During that workshop, no participant felt concerned about productivity or results. Instead, that performance time was dedicated to speculation, which resulted in thinking. To me, the concept of "philoperformance" refers to a specific dimension in space and time, where people may at once act and think, make gestures which result in thought. Thought then finds new impetus in other gestures and so on, moving to and fro between thinking and acting. What I do sets me thinking as an individual, but above all as a member of a community. To me, the tension between individual and community is the crux of philo-performance.

Nadia Vadori-Gauthier: I am a performer in the group "Corps collectif" ("Collective Body", www.lecorpscollectif.com) and a PhD candidate in Decorative Arts at Paris 8 University. I am also a 
coach in Body-Mind Centering and a somatic practitioner. My experience as such illustrates something you pointed out this morning, Flore, a liminal space does exist, where art and philosophy meet, and performance may allow for their practical encounter (Garcin-Marrou 2014b). To me, they meet in some indefinite space we may never fully grasp, a space that may forever remain out of the reach of articulate speech, a "blind" space, with no preconceived word to describe it, something deeply mysterious which, to me, has to do with life itself. Somatic experience and thought are woven together and cannot be conceived as separate. I believe that the body thinks and that a moving body generates thought, just as thought somatizes and shows through the body. For my own part, I began by giving up articulate speech, refusing to associate words with things, refusing to abide by preconceived meaning so as to set off toward an area I could not fathom. Through dancing, I immersed myself in a silence rustling with sensations. At the same time, I started experimenting with new ways of saying poetry and automatic writing, paying attention to the sounds and the rhythms they were made of, to their texture rather than their meaning. I intended to uncover some ways to "stammer in my own tongue", as Deleuze put it, to create unprecedented spaces where meaning could emerge anew. As a bodily explorer, experiencing a speechless space more and more intensely, I began to feel the need to speak. That is when I turned to philosophy. My encounters with concepts turned out to be thrilling emotional events that themselves amounted to somatic experiencing. The latter actually echoed some thoughts just as some philosophers' thoughts interfered with it, in a constant come-and-go. To me, philoperformance consists of such experiencing which provides an affective body for the concept, not making it a formal entity but rather a medium for transformation - a hub of intensity resulting in a chaos which comes into being as experiencing unfolds. I can refer to several concepts which are constantly evolving so long as I start thinking them. That is a two-way process, in constant motion. Everything melts away and is composed anew every second. To me, this is where philosophy and performance meet. It is a truly somatic experience and, therefore, thought incarnate. It is an affective encounter insofar as it has the power to affect while being affected.

Amalia Boyer: I work in Colombia. In the 1980s and 1990s, I started research on a group of women with whom I got involved in what has since become known as 'dance theatre'. This could be considered a philo-performance, revolving around the gaps in what gestures convey. Those women were neither actresses nor professional dancers. Busy as they were, they would meet every night for three hours to work by themselves, outside of any institutional framework or paid job. I wanted to address, first of all, the problems they had to face in their daily lives. That protracted collective work resulted in some sort of a creation which stood out against modern, classic or folkloric dancing. I recorded their gestures and then channeled them into performances, that is to say a living form of art. On the one hand, performance and archive sound incompatible since performance cannot be recorded or kept in the archives. On the other hand, it was important to record what those women were doing, for the sake of future generations. This was happening in a place where nobody would think there would have been such performances, where people behave as if the performing arts had never existed. Where does the power of the archive lie in such a context, faced as it is with such conflicts and tension? 
I was also wondering about my own role as a philosopher. For that matter, my own work underwent some change too: as I was trying to understand those women's work, I felt the need to work just as they were. I moved on to a new way of writing, to a dramaturgy that had to integrate actions and gestures, and could no longer rely on concepts and words. There was no way I could only comment on that work and this is how I came to present a living archive, turning again to a bodily work I thought I had left behind (I was a dancer for 20 years before I turned to philosophy 20 years before that project). How could I bind together those different experiences? And how could I bind individual and collective experiences?

As I was involved in that work, I came across a very important notion in Caribbean Studies, that of "archipelago", a notion I am particularly fond of: how far is each woman an island? How can each woman feel like an outcast? And how can she then realize, as she confronts a group, that her personal issues are in fact shared by most of the others? How can insularity set people off creating an archipelago? The relationship between archipelago and archive allows us to think of an area of thought rather than its mediations, and of a thorough reorganization of the relations between text, gesture, philosophical and performative practices.

Flore Garcin-Marrou: Such insularity is also ours: it is the very condition of that liminal space in which each of us stands, at the crossroads between performance and philosophy. As Avital Ronell (2006) points out in her interviews with Anne Dufourmantelle, French Theory has proved inspirational in American universities, especially as far as female academics are concerned, let us mention Naomi Schor or Jane Gallop for instance, offering performative conferences, wearing next to nothing but ties, in an attempt to discuss Lacan's "double bind". Is it on purpose that my guests today are all women? Is that crossroads where we stand to be understood as a shelter from maleinspired fictions, as a welcoming space for young researchers out of a job? A controversial question that may find no answer, for what is it here that men could not say? How are we to understand that American "boomerang effect", that is to say the fact that the USA sends us back today all that French Theory has inspired there over the last thirty years? On the whole I would say that philoperformance is a way off the beaten tracks of speculative philosophy and allows us to venture into side streets, narrow and unmarked roads that Avital Ronell calls "back roads" and that lead us not to dissociate thought from physical experience anymore, but rather to reconcile physical rhetoric and conceptual rigour.

Maria Kakogianni: I feel like some kind of parasite here. There are two things I would like to draw attention to: our subject and the question of gesture. I am going to beat around the bush first, as I like to do. What is performance philosophy? That is a question I have never really thought of, one that has never appeared to me as something to think over, no more than performance or performativity. Neither can I avail myself of any artistic practice that may have led me to deal with such issues. Hence the feeling I have of being the odd one out. The issue of performance in philosophy is rather something that came crashing down on me one day, as I was defending my PhD. Alain Badiou asked me: "Is your dissertation installation art or a performance?" That day, I started answering that it was more of an installation (the speculative approach of that dissertation had to do with experimental reading). As time passed, I came to realize that what I had done might 
also have been some sort of a gesture. Why? Well, because what my dissertation was dealing with, it was also doing at the same time, which is precisely what Austin calls the "performative".

The second time performativity came crashing down on me was when the French academic establishment argued that my work was unacademic. It did not meet the usual academic standards. What is wrong with my academic gesture? Confronted as we are by the standards our institutions rely on, how should we feel about that failure of a gesture, which was not something I had planned? What can you do when the establishment calls you a "failure"? Someone who is queer did not opt for his or her condition. It just happened that way. And there comes a point when you have to do something about it because the establishment and its standards, which have come to be regarded as natural, mark you out as abnormal or queer.

In the title of this round-table lies a mistake, I think. It lies in the very question in fact. Are we looking for the essence of philo-performance, just as old metaphysics would ask "what is a chair? Has a chair some specific essence?" Or, if not, what are we doing? Let me remind you of one of Judith Butler's key statements according to which "essences should be replaced by performance". And yet, I have some doubts about that postmodern assumption that we are done with the delusions of metaphysics and about that propensity to "set bodies and gestures free", which tends to become a new rule - a final assault on the part of capitalism. This leads me to raise new issues. We are experiencing a radical neoliberal form of violence. If I refer to Austin's definition of the performative as a word that does what it says, what shall I say about the politicians who never do what they say? On the other hand, there are political movements which, as Butler suggested yesterday, are content with the very act of addressing concrete demands to the State without necessarily standing by the claims (Butler 2014). What is a political gesture when it is no speech act? What vision of politics does this convey? What actually "happened" on Syntagma square and the other occupied places (New York, Istanbul, Cairo, Madrid)? Was there any statement? How was it shaped?

Camille Louis: Once more, philo-performance sounds like something very puzzling. Whether it be some space allowing for an encounter, or something that comes crashing down on you, something that we are going back to, or that space in which we need philosophy... It always makes itself felt as a strong attraction enhancing the fact that such an association is far from self-evident. I think that while talking about philo-performance or trying to define it, we are pointing out the fact that philosophy intrinsically needs to reach out for new spaces to develop in, to try and shape itself in a livelier way, in a more dangerous way. Unless we are acting out again some kind of philosophical trend calling itself "philo-performance", despite the fact that it is only taking up the old philosophers' formula according to which they are more poets than the poets themselves. Speaking from where I stand, that is to say as a contemporary philosopher, is there any chance one might imagine some way to depose a specific brand of Western thought and the Western "I" that Catherine Malabou was evoking earlier at this Conference (Malabou 2014), without falling back into some sort of postmodern defeatism? Considering instead that in that "l" - which is not a sovereign "I" - lies some altered power that is pervaded by the other, and that also raises collective issues? There, in that interrelation between philosophy and performance that contaminate each other, does politics come into play - some brand of politics that may not find any practical 
expression if we think that only philosophy may be performance. When the body thinks, it may not be any expression of philosophy. Dancing has a way of thinking that is specifically choreographic. Performance thinks in a specifically performative way. These are the reasons why I feel the need to distinguish performance from philosophy, so as to avoid creating some new monopoly.

Charlotte Hess: I did not mean to impose from the start a shift to the question of gesture, but it is a well-known fact that performance is generally regarded as boiling down to some sort of a language, especially from a philosophical stance. At this stage in our discussion, we have started marking out more clearly the space where we are speaking from when philosophy is at stake. It lies at a distance from academic and purely rational circles. Following Nadia and Amalia's accounts of their respective experiences, especially their somatic experiences, I would like to remind everybody of the fact that the body does not exist. I do not know if we can agree on that point. Dualisms such as body and mind are not only a way of creating a logical difference for thought. They also create hierarchies, dependence, domination. What is the body? To put it plainly, if gesture can be distinguished from the movement of a machine, it is because it has gone through psychic, social, perceptual, coordinating dimensions. There is always a background from which gesture emerges. In other words, gestures do not spring from bodies; they actually shape bodies. I think that somatic practices such as those Nadia evoked, prove very useful to help us think of what Michel Bernard (1995) called "corporeity". As regards what gestures convey, a question that Amalia raised, I would like to point out the fact that if we are all interested in the arts and if the experiences shared here today all testify to a shift from the traditional stage, they also lead us to think of the audience we are supposed to address, and to discuss what "audience" means. Those women you were alluding to, Amalia, who are not professional performers, openly question what we can do together, what it means to create a common space by means of gestures. How can an artist account for that? How can we actually work with people rather than study or portray them? Does the performativity of gestures not require and allow us to shape the stage anew? This is perhaps where aesthetics and politics may meet.

Liza Kharoubi: What you are saying, especially as regards gesture, reminds me of the title of one of Alphonso Lingis's books, The Community of Those Who Have Nothing in Common (Lingis 1994). To me, the specificity of gesture as compared with machines, with the movement of a machine whatever it is, lies in the fact that gesture addresses someone. Gesture is the main movement of ethics. I believe that this ethical dimension comes first, before politics: ethics endows politics with meaning, opens it up. I have also noticed that all our plenary lectures are given by philosophers, though they are also poets. Admittedly, we have created some new spaces to make room for performance, for arts, for the documentary about philo-performance presented by Ajàso, for the collective reading of Antigonick (Ronell et al 2014), but we might be to blame too: although we have empowered a non-mainstream brand of philosophical speech - which is an achievement in itself, a conference lecture is still a philosophical speech. All we can do is to make new adjustments, new shifts. This is what we are doing right now for that matter: while shifting speech from its usual form, we are making a new gesture on the part of philo-performance. Should we not question the very way the conference is shaped? Let this lay the foundations for 2017. 


\section{Flore Garcin-Marrou: 2016!}

Camille Louis: Have you not given this any thought? In fact you have... Unsettling the whole conventional thing, giving up formal talks, creating spaces for discussion... I have no doubt that the idea occurred to you.

\section{Charlotte Hess: Admit it!}

Liza Kharoubi: Alright, we will do our best in 2016.

Esa Kirkkopelto: I come from Helsinki. As I was listening to you, I realized that philo-performance as an issue does not satisfy me. In the course of this 2014 TPP Conference, I have attended some workshops which offered quite beautiful attempts at performing thought. But that raises a few issues, first as regards the way thought relates to arts in general. When it comes to thought and philo-performance, it is often taken for granted that thinking is the privilege of other people: stagedirectors think, choreographers think... Dancers, as for them, just dance and actors act. Thus, philoperformance comes as a liberating process: performers think too. A group of performers is a group that thinks. As a result, everyone's part in a production is to be re-imagined and reassessed. Such emancipation may sound threatening to some people, namely researchers in arts or established critics. If artists themselves start practicing criticism, what is to become of art critics? No wonder tensions are felt, and academic objections to philo-performance are raised. Some of you have described what a hard time you have had trying to have your work acknowledged. This seems to me to be more of a specifically French issue. Today there are countries in Europe where we can do some research that combines theory and practice, the results of which can indeed been considered to be philo-performance.

Marielle Pélisséro: As regards the idea of widening the realm of those who think, Esa, you are saying that actors and performers think. I would like to go even further and argue that the spectators think too. If we are to talk about gesture as addressing someone, as Liza suggested, there must be some other person involved in the process, someone gesture addresses. Spectators are part of the process. We talked about a liminal space earlier. I think there is something in that. We do not stand on the spectator's side or on the performer's. Rather, we stand in-between them. And this is where thought emerges.

Maria Kakogianni: I would like to answer Camille, first of all, regarding her concern about philoperformance being appropriated by conventional philosophy. I would like to defend an indefensible thesis, harking back to Plato's eviction of the poets from his utopian city. Something has been lost in translation. Throughout the text, Plato toys with the ambiguous meaning of the word "poet" (поınтn's) which both refers to producers and to poets strict sensu. Plato argues that the user (the one who uses something) has better episteme than the producer, the poet, which implies that the actor makes better use of the text. What I mean, and that may also answer Esa Kirkkopelto's remarks on France, is that I do not think that there is any specifically French issue as far as research is concerned. The same happens everywhere, and this is what I call the performativity of norms: standards become such; they settle down until they are regarded as 
natural, although they are not. Of course French universities are no more narrow-minded than others. I take it as a matter of fact that any creative gesture is challenging and awkward. First, it is awkward when compared to what we usually call "doing well", "talking well" or "dancing well". Everything new is challenging, not only artistic novelties. If people blame you for being outside the mainstream when you do something, their sentence comes crashing down on you. As regards that brand of philosophy which tends to appropriate new trends and to impose itself as a panopticon to keep an eye on everybody, assessing and judging all that thinks or does not think, I shall say again that it all depends on what we call philosophy. For example, the 1968 gesture of protest makes it clear that politics thinks for itself and does not need philosophy to draw attention to the fact. Art thinks for itself too... Contrary to dancing, architecture or mathematics, for example, which provide spaces for thought to be performed, philosophy, which I have always considered a stranger, does not have a specific space to shape itself: it emerges in-between spaces. Thus, philosophy is hybrid in essence. There are two brands of philosophy: one that admits to its hybrid nature and one that overestimates itself as the most legitimate way of thinking. Because philosophy is intrinsically in that interplay, in-between those two positions, one of those two brands endeavours to appropriate anything new and to do what Camille dreads... But hybrid philosophy is also here to settle between borders and between bodies. Philosophy is philia, that is to say "love" between the various bodies that form a language. Philosophy does not have a body but it arouses love between bodies. We do not know what a body is, but we sometimes witness what happens when two bodies meet.

Aline Wiame: I come from the Université Libre de Bruxelles, Belgium. I would like to respond to the issue of gesture, which I am deeply interested in, and notably to the shift from philoperformance to gesture, a shift that Charlotte mentioned when she described her practice. That means a lot to me, because I am not too fond of the term 'philo-performance': I agree that "performance philosophy" works, but I have doubts as far as "philo-performance" is concerned. In Brussels, I have worked most notably with Isabelle Stengers. When she retired last year, she and her research group GECo - a research group in constructivist studies - organized a conference in Cerisy that was entitled "Gestes speculatifs" ("Speculative Gestures", Stengers and Debaise 2013). All her academic circle took part in it, people such as Tobie Nathan, Bruno Latour, Donna Haraway, etc. They had all admitted to the issue of "located gestures". But the meaning that emerged quite spontaneously from the various talks was an idea that Stengers would call an "ecology of practice", that is to say, a speculative gesture. How can we, in our own practice, create a gesture that would be either theoretical or practical in essence? What gestures may be imagined to challenge what does not work in one's own practice? Where, when, why should we make a gesture? The issue was raised by Tobie Nathan in the field of psychiatry, but also by lawyers who discussed the way they should break some rules so as to improve law, setting a precedent to allow for progress. Pondering this, I am realizing that what a speculative gesture and an ecology of practice allow me to think may well be a way to outgrow the question of what performance and philosophy actually are - a question that may itself become a snare since it implies that we keep laying the foundations for their encounter without ever developing the various shapes it may take, knowing that the performer him- or herself speculates too, using speculation as a way to create possibilities, and also as a way to resist critical thought... This is also at the back of the workshop on speculative 
story-telling that I offered earlier today, along with Fabrizio Terranova, a workshop that was inspired by Donna Haraway's speculative fabulations. Speculative story-telling aims at experimenting with other ways to shape a community through narratives that point to future possibilities rather than harking back to categories inherited from original myths. This makes them performative narratives that create possibilities out of heterogeneous material, just as postdramatic theatre challenges the structural patterns of ancient tragedy. Rather than criticizing and deconstructing, what type of possibilities can thought open up through a series of practices? Here are some alternative ways of envisioning the field of philosophical performance.

Mélanie Perrier: I have been co-chairing the Laboratoire du geste ("Gesture research group", www.laboratoiredugeste.com) since its creation in 2005, along with Barbara Formis, and what I am interested in is gesture as a practical tool to think what may happen in the realm of performance but also to shift thought from its usual locus. It allows us to unsettle the shapes thought may take, its agents, the postures of those who think, without any demand for productivity - which makes a great difference. How does gesture express itself? I would also like to ask that question: what could be a training session for philosophers?

Amalia Boyer: I would answer that it is easier for people to acknowledge that an artist thinks too. But the reverse is even more difficult: how can a philosopher, settled as he is in his position, do anything with his body? To someone who reads and writes philosophy, everything is fine as long as bodies are said to be dominated by minds and concepts. By all means, never stand up and do anything, especially in front of others! We should nonetheless keep in mind the tradition of philosophers who have mused over the body and encouraged us to experiment with it.

Nadia Vadori-Gauthier: I have been listening for a while and something in me both surrenders and gets excited. To me, what philo-performance or the body are, or even what performance is, does not really matter. We do not know much about what performance is, except that it is to be found in some liminal spaces. It would have to be experienced as a process, to be shaped through experience, and philosophy or performance should be used as means to set this research process off and to ask questions. And even if I am interested in the notion of gesture, that single word comes short of a suitable definition. Taking after Spinoza - that is to say, wondering not so much what a body is but rather what it can do - I would rather explore what performance and philosophy can do. What can they do jointly if not unsettling, occupying the cracks, maybe here, to start with [at that point, she goes and sits on a bench in the audience]. What can philosophy and performance do? Just... [she tilts backward] I a-a-a-a-am sli-i-iding - I am sliding into the-e-e cra-a-ack-k-k [she sinks to the floor between the benches, her feet up in the air], I - am - crumbling to pi-i-ieces, I - a-a-a-am, I am... [she sits back up] coming back to Spinoza. [She is about to throw the table over but stands up instead, climbs up on a bench, turns to the audience, starts a slightly swinging dance]. I am getting in touch with you [she takes a spectator's hands in hers], I am getting in touch with you, I am getting in touch with you [she makes bodily contact with various people. She undresses]. I do not know what I am doing, I do not know if that is a gesture or a performance [she walks on the benches and across the room, naked, until she sits down in the back row]. I do not have a question. 
1 "What we mean by "philo-performance" is the staging of thought, whatever shape that may take: spoken and acted-out philosophy, slam poetry, public talks, dancing, practical research, official and alternative festivals, etc... We intend to explore that area where concept becomes practical and knows itself to be performing, and the way philosophy may shape itself through performance, opening up and uncovering spaces for itself." ("Par philoperformance, nous entendons la mise en scène de la pensée sous toutes ses formes: philosophie parlée et joutée, slam, intervention sociale, danse, recherche-action, festivals et anti-festivals... Notre ambition est d'explorer cette zone où le concept est en action, se fait performatif, la manière dont la 'philo' peut se faire par la performance, en ouvrant et trouvant ses propres espaces.")

\section{Works Cited}

Bernard, Michel. 1995. Le Corps. Paris: Les Éditions du Seuil.

Butler, Judith. 2014. "When Gesture Becomes Event." Paper presented at Theatre, Performance, Philosophy International Conference, Paris, June 27. Accessed 8 March 2015. http://labo-laps.com/videos-theatreperformance-philosophie-tpp-2014/.

___. 2006. Gender Trouble. London and New York: Routledge.

Carson, Anne. 2012. Antigonick. Tarset: Bloodaxe Books.

Corps collectif. Website. Accessed 8 March 2015. http://www.lecorpscollectif.com.

Deleuze, Gilles. 1977. Dialogues. Paris: Flammarion.

Garcin-Marrou, Flore. 2014a. "Pour un théâtre écosophique" ("Towards an ecosophic theatre"). Accessed 8 March 2015. http://labo-laps.com/theatre-ecosophique/.

2014b. "Comment Avital Ronell performe-t-elle sa pensée?" ("How does Avital Ronell perform her thought?"). Paper presented at Theatre, Performance, Philosophy International Conference, Paris, June 28. Accessed 8 March 2015. http://labo-laps.com/videos-theatre-performance-philosophie-tpp-2014/.

___. 2013. "Théâtre(s) clinique(s)" ("Clinical theatres"). Chimères, 80 ("Squizodrama and schizo-scenes").

2012. "To Be or Not to Be Socrates: Introduction to the Translation of Félix Guattari's Socrates." Deleuze Studies 6 (2): 170-72. http://dx.doi.org/10.3366/dls.2012.0055.

Haraway, Donna. 2011. SF: Speculative Fabulation and String Figures. Number 033 of Documenta: 100 Notes, 100 Thoughts: Ostfildern: Hatje Cantz.

Kirkkopelto, Esa. 2008. Le Théâtre de l'expérience. Contributions à la théorie de la scène. Paris: Presses de l'Université Paris-Sorbonne.

Kompost. Website. Accessed 8 March 2015. http://kompost.me.

Labex Arts $\mathrm{H} 2 \mathrm{H}$. 2014. Cognition, danse et performance avec un dispositif numérisé ("Cognition, Dance and Performance in the Age of Digital Technology"). CNRS/Université Paris 8 - Université Paris-Ouest. Accessed 8 March 2015. http://www.labex-arts-h2h.fr/cognition-danse-et-performance-176.html.

Labo LAPS (Laboratoire des Arts et Philosophies de la Scène). Website. Accessed 8 March 2015. http://labolaps.com/.

Laboratoire du geste. Website. Accessed 8 March 2015. http://www.laboratoiredugeste.com.

Lingis, Alphonso. 1994. The Community of Those Who Have Nothing in Common. Bloomington: Indiana University Press. 
Malabou, Catherine. 2014. "Performance and Power: an interrogation." Paper presented at Theatre, Performance, Philosophy International Conference, Paris, June 27. Accessed 8 March 2015. http://labolaps.com/videos-theatre-performance-philosophie-tpp-2014/.

Panopoulos, Dimitra, and Flore Garcin-Marrou, organisers. 2012. Conference: Images et fonctions dans la philosophie française contemporaine ("Images and Functions in French Contemporary Philosophy"), Ecole Normale Supérieure, Paris, 19-20 October, 23-24 November. Accessed 8 March 2015. http://labolaps.com/argument-du-colloque-images-et-fonctions-du-theatre-dans-la-philosophie-francaisecontemporaine/.

Plana, Muriel. 2014. "Jeunes scènes queer françaises". Paper presented at Theatre, Performance, Philosophy International Conference, Paris, June 27. Accessed 8 March 2015. http://labo-laps.com/videos-theatreperformance-philosophie-tpp-2014l

Plato. 2000 [380 BCE]. The Republic. Translated by Benjamin Jowett. Mineola NY: Dover Publications.

Puchner, 2014. "Scenes of Instruction." Paper presented at Theatre, Performance, Philosophy International Conference, Paris, June 26. Accessed 8 March 2015. http://labo-laps.com/videos-theatre-performancephilosophie-tpp-2014l.

Ronell, Avital. 2006. American Philo. Entretiens avec Anne Dufourmantelle. Paris: Stock.

Ronell, Avital, Elisabeth Angel-Perez, Judith Butler, Karen Shimakawa, Freddie Rokem, Opie Boero Imwinkelried, Timothy Murray, Paul Monaghan, Laura Cull, and Jon McKenzie. 2014. Public reading of Anne Carson, Antigonick, presented at Theatre, Performance, Philosophy International Conference, Paris, June 26. Accessed 8 March 2015. http://labo-laps.com/videos-theatre-performance-philosophie-tpp-2014/.

Spinoza. 2005 [1677]. Ethics. Translated by Edwin Curley. London: Penguin Classics.

Stengers, Isabelle, and Didier Debaise, organisers. 2013. Conference: Gestes spéculatifs ("Speculative Gestures"), Centre Culturel International, Cerisy, June 28-July 5.

\section{Biographies}

Speakers:

Amalia Boyer is a full-time professor at Bogotá's Universidad del Rosario, Colombia. She is doing research with a group of women involved in theatrical dancing. Publications and research interests: French contemporary thought, aesthetics, Caribbean thought, feminist theory.

Flore Garcin-Marrou is an associate lecturer in Theatre Studies at the Universities of Paris 3 and Strasbourg. She holds a PhD in French Literature from the Sorbonne. Her dissertation is entitled Gilles Deleuze, Félix Guattari: Between Theatre and Philosophy. In 2010, she launched the Labo LAPS, a French research group in performance philosophy. She is a member of Performance Philosophy. She is one of the co-organizers of the TPP 2014 Conference.

Charlotte Hess is a tango dancer and a performer. She used to study both performing arts and philosophy at Paris 8 University. Over the last decade, she has been a member of a group of artists named "philo-performance". Together they intend to stage thought.

Maria Kakogianni is an associate lecturer in Philosophy at Paris 8 University. Her dissertation is entitled Théorème de la "femme dans l'oikos". Lectures expérimentales pour s'émanciper du récit de la victime ("The Theorem of Woman in Oikos. An Experimental Reading Going beyond Victimization Narrative"), supervised by Alain Badiou (2008). 
Liza Kharoubi is a lecturer in Contemporary British Theater at the University of Avignon. Her dissertation is entitled The Face of the Stage: The Other World of Harold Pinter and Emmanuel Levinas. She is a former participant in the Mellon School for Theatre and Performance Research at Harvard University as well as a member of VALE and the Labo LAPS. As the founder and an active member of the group Performance Philosophy France, she seeks to encourage the development of that new research field in that country. She is one of the co-organizers of the TPP 2014 Conference.

Esa Kirkkopelto is a philosopher, an artist-researcher, a performer and a former theatre director and playwright. Since 2007, he has been working at the Theatre Academy (University of Arts, Helsinki) as a Professor of Artistic Research. He defended his PhD in Philosophy in 2002 at the University of Strasbourg. He is the author of Le Théâtre de l'expérience. Contributions à la théorie de la scène. He is a core-convener of the Performance Philosophy Association.

Camille Louis is a playwright and a PhD candidate at Paris 8 University, where she is also an associate lecturer. Her dissertation is entitled: La Recomposition du politique dans la décomposition des politiques ("Re-membering Politics While Dismembering Policies"). Working at the crossroads between philosophy and arts, she organizes performative talks in the framework of the various research groups she takes part in: Kom.post, the Laboratoire tournant and l'Archipel des devenirs.

Marielle Pélisséro is a PhD candidate at Paris Ouest - Nanterre University and an associate lecturer in scenography at the University of Aix-Marseille. Her dissertation focuses on the emergence of performance in France since the 1960s, on the necessity of such a concept and of the ways it is used.

Mélanie Perrier is a choreographer and a lecturer at the Department of Arts at the Sorbonne. She has worked with Barbara Formis as the co-founder and co-director of the Laboratoire du geste ('The Gesture Research Group') since its creation in 2005. It is a platform which promotes research, publication and creation in performing arts.

Nadia Vadori-Gauthier is a performer in the group "Corps collectif" ("Collective Body"). She holds a PhD in Decorative Arts from Paris 8 University. Her dissertation is entitled Du mouvant. Processus somatique de création individuelle et collective d'images et de formes vivantes ("On Animated Forms. The Somatic Process of Creating Individual and Collective Images and Live Forms"). She is also a coach in Body-Mind Centering and a practitioner of somatic experiencing.

Aline Wiame holds a PhD in philosophy from the Université Libre de Bruxelles. Her dissertation is entitled La Défiguration dans l'écriture théâtrale du vingtième siècle et ses implications philosophiques ("Dis-figuration in 20thCentury Drama and its Philosophical Implications"). In 2013-2014, she was a Visiting Scholar at the Department of Philosophy of Penn State University, USA. She is a member of the Labo LAPS.

Translator: Virginie Girel-Pietka is an associate lecturer in English at Sorbonne Nouvelle - Paris 3 University. She holds a PhD in Irish drama from Lille 3 University. Her dissertation is entitled La Crise de l'identité dans le théâtre de Denis Johnston ("Denis Johnston's Stage Plays: Staging Identity in a crisis").

(c) 2015 Amalia Boyer, Flore Garcin Marrou, Charlotte Hess, Maria Kakogianni, Liza Kharoubi, Esa Kirkkopelto, Camille Louis, Marielle Pélisséro, Mélanie Perrier, Nadia Vadori-Gauthier, Aline Wiame

Except where otherwise noted, this work is licensed under a Creative Commons AttributionNonCommercial-ShareAlike 4.0 International License. 